\title{
The Effect of Finishing Milling Parameters on the Physico-Mechanical Properties of the Structural Steel Surface Layer of Aircraft Parts
}

\author{
V.D. Vermel, S.A. Bolsunovsky, Yu.O. Leontyeva* \\ Central Aerohydrodynamic Institute named after Professor N.E. Zhukovsky, \\ Zhukovsky ul., 1, Zhukovsky, Moscow Region, 140180, Russia \\ * Corresponding author: Tel.:+7 (926) 97380 80.E-mail: juliana.leonteva@mail.ru
}

\begin{abstract}
In modern conditions, a technological milling process of aviation parts implemented on a new generation of CNC machines using carbide cutting tools with hardening coatings modified with nanomaterials, high-speed milling applied for parts made of metal structural materials is of particular importance.

High-speed milling differs from traditional milling by increasing the cutting speed by 10 times or more. Increasing the cutting speed and changing a number of other parameters of the high-speed milling process leads to a significant increase in cutting zone temperature and a change in the physico-mechanical properties of the sample surface layer, different from those that arise during traditional milling processing. In turn, the state of the surface layer affects the performance characteristics of parts - strength (static, cyclic, impact), wear resistance, resistance to corrosion, erosion and cavitation.

A significant increase in the performance of high-speed milling is achieved by fulfilling the conditions for the correct selection of the cutting tool for the type, condition and configuration of the processed material surfaces, as well as determining the optimal parameters for high-speed milling, which maintains high performance characteristics of aircraft parts.

The paper presents the results of determining the state of the surface layer of structural steel samples of grades 30HGSA and EP 817 used for the manufacture of compressor machine blades, sheathing housings, flanges and loaded parts of aircraft structures operating under alternating loads, respectively, after traditional and high-speed milling at different cutting speeds.
\end{abstract}

\section{Keywords}

High-speed milling; strain hardening; structural steels; residual stresses; microstructural analysis; chemical analysis.

(C) V.D. Vermel, S.A. Bolsunovsky, Yu.O. Leontyeva, 2020

\section{Introduction}

The state of the surface layer of parts after milling determines the operational properties of the finished products (strength, wear resistance, resistance to corrosion, erosion and cavitation), thereby establishing their service life and other indicators of reliability and durability [1]. Establishing the laws governing the influence of milling parameters on the state of the surface layer makes a significant contribution to the process of optimizing the conditions and parameters of high-speed milling, ensuring high productivity of milling processing of aviation parts while maintaining their high performance [2].

The nature of the formation of the surface layer properties of parts during milling is determined by power and temperature effects. During processing, temperatures arise at the cutting zone, at a value of which (0.25-0.3) $T_{\text {melt }}\left(T_{\text {melt }}\right.$ - melting temperature) the deformed material of the surface layer returns, at a temperature above $0.4 T_{\text {melt }}$ - recrystallization occurs, accompanied by a partial or complete removal of strain hardening. So, during milling processing in the surface layer two mutually exclusive processes occur: strain hardening and softening. The state of the sample surface layer is determined by the ratio of the intensity and speed of these processes [3-5].

The structural phase state of the surface layer is determined by elastoplastic deformation, local heating and chemical interaction of the processed material in the cutting zone with the material of the cutting tool 
and the environment. An increase in temperature during processing creates the conditions for the transition of the material to a high-temperature structural-phase state, while rapid cooling after heating contributes to the occurrence of martensitic transformations. To study the structural phase state, direct methods, such as diffraction and microscopic methods, are mainly used.

As a result of simultaneous inhomogeneous occurrence of plastic deformation and phase transformations in the surface layer, residual stresses arise. The stress distribution in the sample surface layer after milling is due to several factors: mechanical (plastic deformation), thermal (surface heating) and force factor (direction of the force load acting on the processing surface). Depending on the processing parameters, the resulting effect can be exerted by a mechanical factor - compressive stresses arise on the surface, thermal factor - tensile stresses arise, or force factor - tensile or compressive stresses arise depending on the direction of the force field. Residual stresses in the surface layer up to $2 \cdot 10^{-2} \mathrm{~mm}$ thick are determined by the non-destructive X-ray method.

In [6], models for calculating the loads acting on products during their operation and the effect of residual stresses on fatigue strength are considered. The effect of alternating loads complicates the plastic flow of the metal, and in this case, residual stresses have a significant effect on fatigue strength: tensile stresses reduce fatigue strength, while compressive stresses increase it. Residual macrostresses also affect brittle fracture resistance. The presence of residual stresses can lead to a decrease in the margin of operational strength, and the overload effect starts the process of crack development, which negatively affects the bearing capacity of the part up to catastrophic failure [7].

The depth of the strain hardening layer is measured from the maxima of the material protruding on the treated surface to the upper level of the material region with the physico-mechanical properties of the starting material. The degree of hardening and the thickness of the riveted layer depend on the method and processing conditions; the average thickness is from a few micrometers to 200-500 microns when milling. Under adverse milling conditions (low cutting speed with high feed and cutting depth, negative rake angles), the hardening depth can reach $1 \mathrm{~mm}$ or more. The established value of the hardening depth allows developing the technological process for milling a part taking into account changes in the properties of the material surface layer. Among the various methods for determining the value of the hardening depth, X-ray diffraction analysis is distinguished.
This paper presents the study results of the influence of different cutting speeds on the surface layer during milling of parts made of aircraft structural steels 30KhGSA and EP817 with increased corrosion resistance.

\section{Problem statement}

Modern technological advances determine the widespread use of aviation materials, the milling of which using existing technologies is a difficult task. Hardened structural steels can be processed by grinding, however, tensile residual stresses and burns occur in the surface layer. The use of high-speed milling in some cases eliminates the use of finishing operations such as grinding. High-speed blade processing allows forming the surface layer of parts with optimal values of roughness, depth and degree of hardening, residual stresses and structural-phase composition, without requiring additional tools and equipment.

Steels are usually milled without the use of a lubricating coolant with external cooling and removal of chips with a jet of air. In the cutting zone, the temperature rises up to about $1000^{\circ} \mathrm{C}$, while at traditional milling it is about $300-400{ }^{\circ} \mathrm{C}$. Chips are formed as a result of high-temperature plastic deformation instead of a force shift by the cutter teeth. The use of coolant leads to sharp changes in temperature at the edge of the cutting tool and its accelerated destruction due to thermal fatigue.

The cutting speed and feed have a significant impact on the hardening depth in structural steels. With an increase in the cutting speed, the heating temperature and strain rate increase, but the duration of stress and the heating time of the sample surface layer decrease. An increase in heating of a deformed metal with an increase in the cutting speed leads to an increase in the diffusion mobility of atoms, activation of the softening processes, and reduction in the intensity of the surface layer strain hardening, which contributes to a decrease in the hardening depth of the surface layer [1].

An increase in the front and rear angles of the cutting tool and the use of coolant also reduce the hardening depth.

The feed has the strongest effect on the surface layer hardening. There is an optimal feed at which the hardening depth is the least.

The cutting depth during milling does not have a noticeable effect on the surface layer hardening [1].

Depending on the physico-mechanical properties and the milling mode, the hardening depth in structural steels is several millimeters for roughing and 
hundredths or thousandths of a millimeter for finishing. More plastic materials when cutting are characterized by a greater hardening depth.

The aim of this work was to study the state of the surface layer of samples from structural steels EP817 and $30 \mathrm{HGSA}$ after milling at various cutting speeds.

\section{Experiments: methods and materials}

\section{Sample materials}

Steel EP817 (Table 1) refers to corrosion-resistant martensitic aging steels. It is used for the production of loaded aircraft assemblies operating at temperatures from -70 to $+300{ }^{\circ} \mathrm{C}$ in general climatic conditions in contact with fuel.

Before the experiment, the EP817 steel sample was hardened, which corresponds to the conditions for finishing milling of parts.
Steel 30HGSA (Table 2) is structurally alloyed steel obtained in electric arc steel furnaces. Compressor blades, sheathing housings, flanges, and other critical parts of aircraft structures operating under alternating loads at temperatures up to $200{ }^{\circ} \mathrm{C}$ are made of 30HGSA structural steel [9].

\section{Milling samples}

A sample made of steel EP817 with dimensions of $260 \times 120 \times 20 \mathrm{~mm}$ was located in the geometric center of the working desk of a DMU-70eVo CNC milling machine.

The sample was subjected to passing fine milling using a SKIF D16R8 spherical milling cutter with a monoplate (angle of inclination $-45^{\circ}$, allowance from above). During processing, zones with a width of $30 \mathrm{~mm}$ (No. 1 and No. 7 in Table 3) were distinguished.

The chemical composition of steel EP817 [8]

Table 1

\begin{tabular}{ccccccccccc}
\hline $\begin{array}{l}\text { Steel } \\
\text { grade }\end{array}$ & \multicolumn{1}{c}{ C } & \multicolumn{7}{c}{ The content of chemical elements, \% (by weight) } \\
\hline EP817 & $0.05-0.08$ & $13.5-14.5$ & $5.6-6.2$ & $1.8-2.2$ & $0.03-0.1$ & $1.3-1.7$ & $0.25-0.4$ & up to 0.7 & up to 1.0 \\
\hline
\end{tabular}

Note: $\mathrm{C}$ - carbon; $\mathrm{Cr}$ - chromium; $\mathrm{Ni}$ - nickel; $\mathrm{Cu}$ - copper; $\mathrm{Ti}$ - titanium; $\mathrm{Mo}$ - molybdenum; $\mathrm{Nb}$ - niobium; $\mathrm{Si}$ - silicon; $\mathrm{Mn}$ - Manganese.

Table 2

The chemical composition of steel 30HGSA [10]

\begin{tabular}{ccccccc}
\hline \multirow{2}{*}{ Steel grade } & \multicolumn{5}{c}{ The content of chemical elements, \% (by weight) } \\
& $\mathrm{C}$ & $\mathrm{Si}$ & $\mathrm{Mn}$ & $\mathrm{Cr}$ & $\mathrm{Ni}$ & $\mathrm{Cu}$ \\
\hline 30HGSA & $0.28-0.35$ & $0.9-1.2$ & $0.8-1.1$ & $0.8-1.1$ & up to 0.3 & up to 0.3 \\
\hline
\end{tabular}

Technological parameters of milling processing for steel EP817

Table 3

\begin{tabular}{clcccccc}
\hline $\begin{array}{c}\text { Processing } \\
\text { zone No. }\end{array}$ & Type of cutter & $A_{e}$ & $A_{p}$ & $V_{c}, \mathrm{~m} / \mathrm{min}$ & $N, \mathrm{rpm}$ & $F, \mathrm{~mm} / \mathrm{min}$ & $F_{z}, \mathrm{~mm}$ \\
\hline 1 & SKIF D16R8 & 0.3 & 0.5 & 182 & 3980 & 1350 & 0.17 \\
2 & SKIF D16R8 & 0.3 & 0.5 & 273 & 5970 & 2030 & 0.17 \\
3 & SKIF D16R8 & 0.3 & 0.5 & 364 & 7960 & 2700 & 0.17 \\
4 & SKIF D16R8 & 0.3 & 0.5 & 455 & 9950 & 3380 & 0.17 \\
5 & SKIF D16R8 & 0.3 & 0.5 & 636 & 13920 & 4740 & 0.17 \\
6 & SKIF D16R8 & 0.3 & 0.5 & 818 & 17900 & 6088 & 0.17 \\
7 & SKIF D16R8 & - & - & 50 & - & - & - \\
\hline
\end{tabular}

Note: $A_{e}-$ a step between processing lines; $A_{p}-$ the machining allowance; $V_{c}-$ the cutting speed; $N-$ the spindle speed; $F-$ the minute feed of the tool; $F_{z}-$ the feed to the cutter tooth. 
The parameters of high-speed processing with a sequential increase in the cutting speed as a factor determining the temperature conditions in the cutting zone (from $182 \mathrm{~m} / \mathrm{min}$ for zone 1 to $818 \mathrm{~m} / \mathrm{min}$ for zone 6) are given in Table 3 . The processing zone No. 7 corresponds to traditional finishing milling.

Samples with dimensions of $20 \times 15 \times 15 \mathrm{~mm}$ were cut out from each zone using the EDM machine and marked in accordance with Table 3.

Samples for steel 30HGSA were prepared similarly.

\section{Preparation of steel microsections for research}

The samples of structural steels EP817 and 30HGSA are shown schematically in Figs. $1 a, b$, respectively.

To prepare microsections, the equipment of the Struers company (Denmark) was used:

- a small-sized TegraPol-31 grinding and polishing machine with a holder for automatic grinding and polishing of TegraForce-5 samples and a system for automatic dispensing of suspensions for polishing TegraDoser-5 (Fig. 2a);

- an equalizer of samples in the Uniforce holder (Fig. 2b).

The mechanical preparation (grinding and polishing) of each sample was carried out according to the guidelines and preparation theory of materialographic samples [11] on the surface adjacent to the milled surface at right angles (Figs. 1 $a, b$ ). On this surface, the studied region of the surface layer is highlighted in gray.The thickness of the removed material during preparation is $(0.9 \pm 0.05) \mathrm{mm}$.

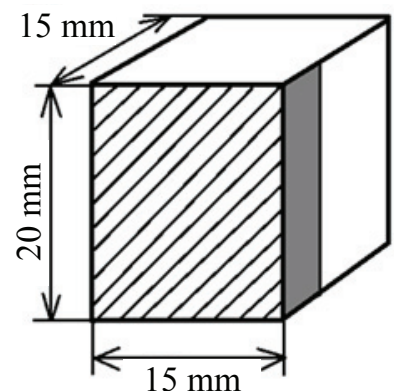

a)

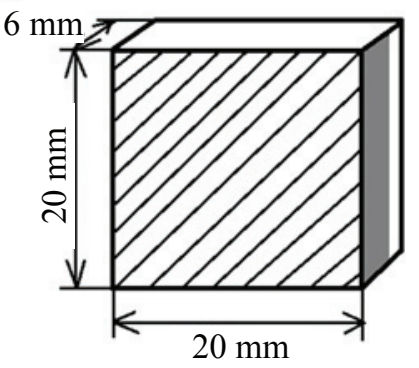

b)
Fig. 1. Schematic representation of structural steel samples: $a$ - EP817; $b-30$ HGSA

QD-surface layer after milling; - studied area of the surface layer

\section{Results and discussion}

The analysis of the surface layer of steel EP817 and 30HGSA samples was carried out in several stages.

To conduct microstructural analysis, chemical etching of microsections was performed by immersion in specially prepared reagents $[12,13]$.

Microsections of steels EP817 and 30HGSA after etching are shown in Figs. $3 a, b$, respectively.

The microstructural analysis of steel EP817 microsections was carried out using a Quanta 200 FEI Inspect Scanning Electron Microscope (SEM) (Fig. 4).

The results of the microstructural analysis made it possible to determine the structural-phase composition of the surface layer of EP817 steel samples and the presence of visible deformation in the surface layer, as well as to estimate the approximate hardening depth [14-18].

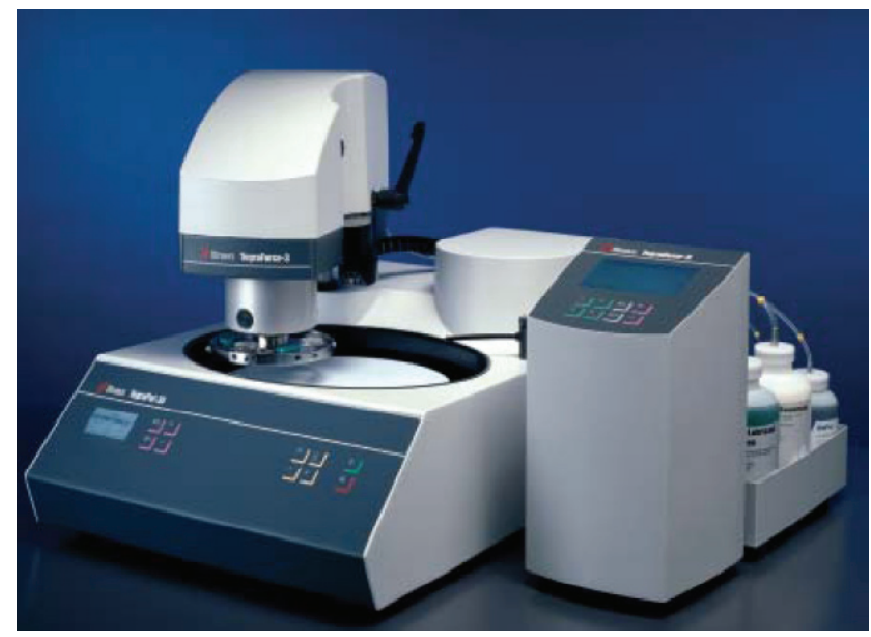

a)

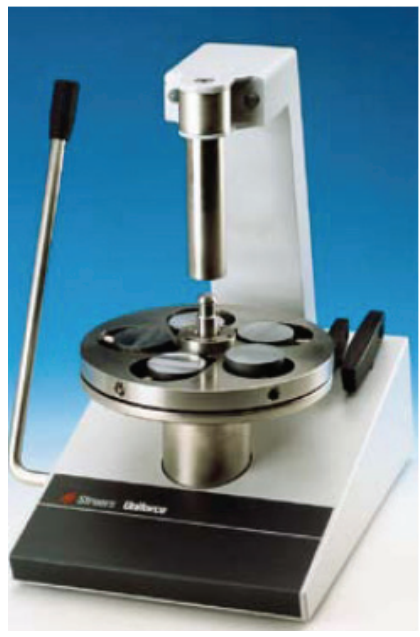

b)

Fig. 2. Equipment for preparing microsections (Struers, Denmark): $a$ - grinding and polishing machine TegraPol-31; $b$ - Uniforce equalizer 


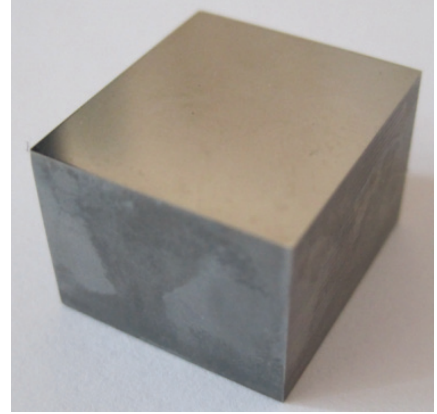

a)

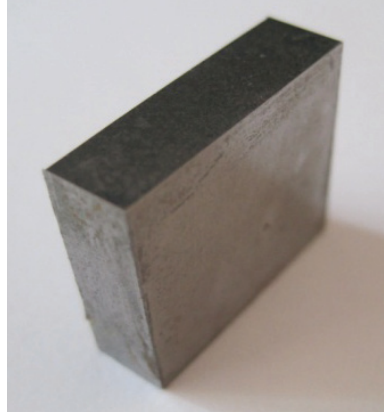

b)
Fig. 3. Microsections after mechanical preparation and etching: $a$-steel EP817; $b$ - steel 30HGSA

It was revealed that after traditional milling processing in the surface layer, there is no significant plastic deformation. A similar result was obtained for high-speed milling processing with cutting speeds of 182,364 and $455 \mathrm{~m} / \mathrm{min}$. A photograph showing the microstructure of the surface layer of the EP817 steel sample after processing at a cutting speed of $364 \mathrm{~m} / \mathrm{min}$ is presented in Fig. 5.

Processing with cutting speeds of 273, 636 and $818 \mathrm{~m} / \mathrm{min}$ led to plastic deformation in the surface layer, which can negatively affect the physicomechanical characteristics of the surface layer. A photograph showing the microstructure of the surface layer of the EP817 steel sample after processing at a cutting speed of $273 \mathrm{~m} / \mathrm{min}$ is presented in Fig. 6 .

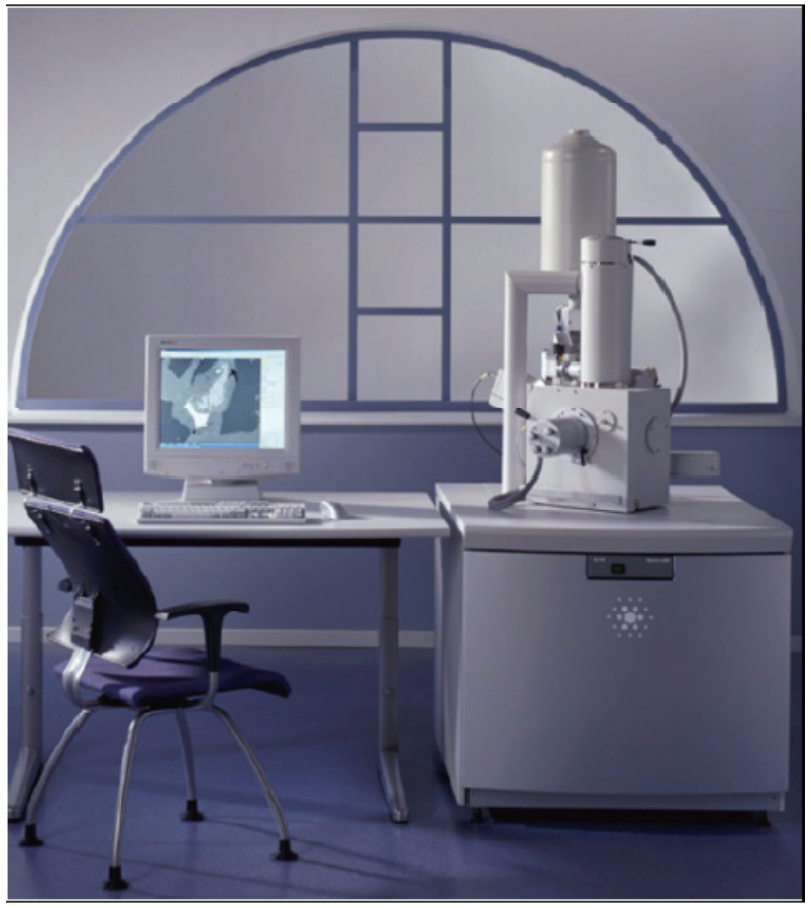

Fig. 4. Scanning Electron Microscope Quanta 200 (FEI Inspect Scanning Electron Microscope)

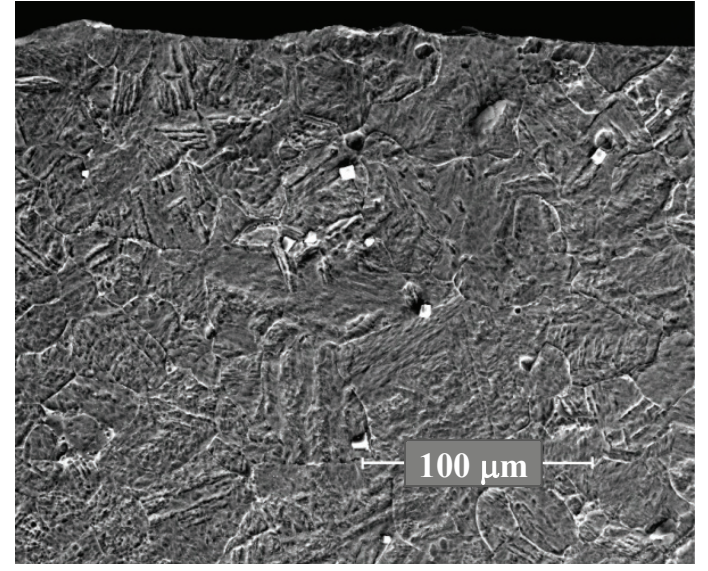

Fig. 5. Microstructure of the surface layer of a steel sample EP817 after milling with a cutting speed of $364 \mathrm{~m} / \mathrm{min}, \times 1000$

The microstructure of samples made of 30HGSA steel was studied using a JSM-6490LV scanning electron microscope. The microstructural analysis showed that the most severe damage to the sample surface occurred during the traditional milling mode at a cutting speed of $45 \mathrm{~m} / \mathrm{min}$. In this treatment mode, deep bursts of metal and nadir formed, which is clearly visible in the microstructure photograph (Fig. 7). The hardening depth was approximately $10 \mu \mathrm{m}$.

The high-speed milling did not lead to plastic deformation of the surface layer for the entire range of cutting speeds considered, while with an increase in the cutting speed, the surface quality improved (Fig. 8).

For the traditional milling mode and the entire range of high-speed milling modes, no phase changes were observed in the microstructure associated with steel heating above the temperature at the onset of austenitic transformation.

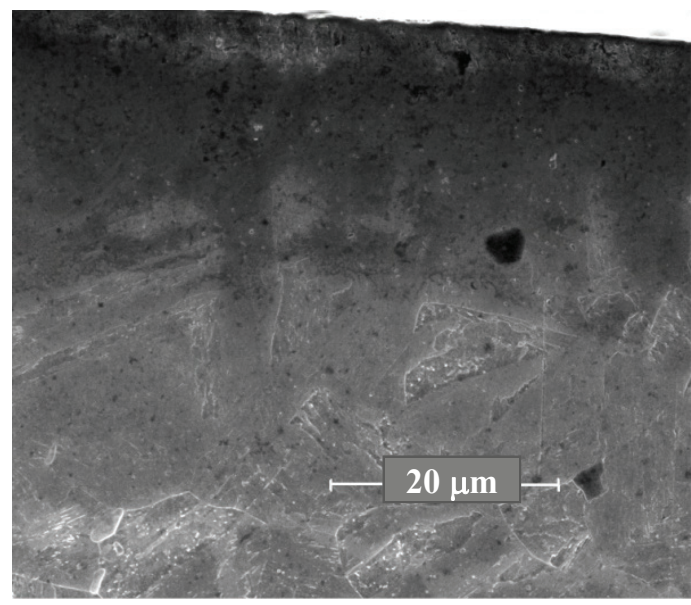

Fig. 6. Microstructure of the surface layer of a steel sample EP817 after milling with a cutting speed of $273 \mathrm{~m} / \mathrm{min}, \times 5000$ 


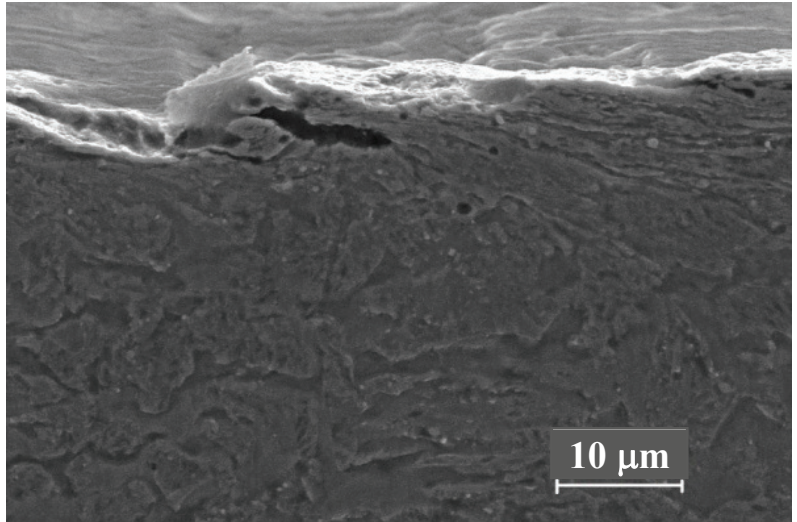

Fig. 7. Microstructure of the surface layer of a steel sample 30HGSA

after traditional milling processing, $\times \mathbf{2 0 0 0}$

The use of an electron microscope made it possible to perform a qualitative analysis of some parameters of the surface layer. To carry out a quantitative assessment, the method of X-ray structural phase analysis was used, which allowed to determine the phase composition, value and sign of residual stresses and hardening $[19,20]$. Such a study was done for 30HGSA steel samples.

The study of hardening in the surface layer of 30KhGSA steel samples after milling was carried out by X-ray diffraction analysis in comparison with a reference sample obtained by grinding, mechanical and electrochemical polishing. The $\mathrm{X}$-ray diffraction was

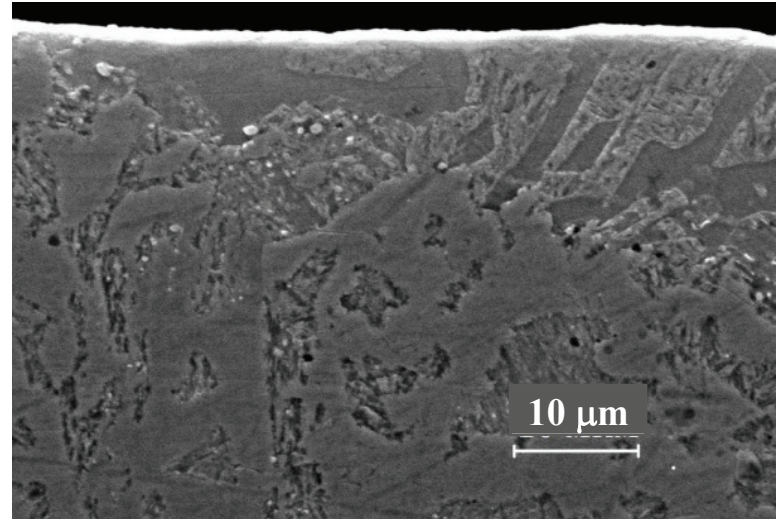

Fig. 8. Microstructure of the surface layer of a steel sample $30 \mathrm{HGSA}$ after milling with a cutting speed of $364 \mathrm{~m} / \mathrm{min}, \times 2000$

recorded using a DRON-4 X-ray diffractometer in monochromatized $\mathrm{Cu}-\mathrm{K} \alpha$ radiation, the voltage was $30 \mathrm{kV}$, and the current was $20 \mathrm{~mA}$.

In order to determine the causes of the physical broadening of the X-ray lines in the $\alpha$-phase (ferrite), the ratios of the physical broadening of lines (101) and (220) were determined. It was found that the ratio of the physical broadening $\beta_{1} / \beta_{2}$ is almost equal to the ratio of the tangents of the corresponding Bragg angles $\operatorname{tg} \theta_{1} / \operatorname{tg} \theta_{2}$ (Table 4). Thus, it has been shown that the cause of the physical broadening is metal hardening [20].

Table 4

The results of determining the physical broadening of X-ray lines (101) and (220) in the $\alpha$-phase

\begin{tabular}{|c|c|c|c|c|c|c|c|}
\hline Sample No. & HKL & $2 \theta, \operatorname{deg}$ & $\theta, \mathrm{rad}$ & $\beta$ & $\operatorname{tg} \theta_{1} / \operatorname{tg} \theta_{2}$ & $\cos \theta_{2} / \cos \theta_{1}$ & $\beta_{1} / \beta_{2}$ \\
\hline \multirow{2}{*}{1} & 101 & 44.885 & 0.391696 & 0.27677 & \multirow{2}{*}{0.35265} & \multirow{2}{*}{0.702529} & \multirow{2}{*}{0.368782} \\
\hline & 220 & 99.019 & 0.864104 & 0.750497 & & & \\
\hline \multirow{2}{*}{2} & 101 & 44.992 & 0.392629 & 0.168963 & \multirow{2}{*}{0.35111} & \multirow{2}{*}{0.699945} & \multirow{2}{*}{0.337219} \\
\hline & 220 & 99.416 & 0.867568 & 0.50105 & & & \\
\hline \multirow{2}{*}{3} & 101 & 45.027 & 0.392935 & 0.156301 & \multirow{2}{*}{0.35127} & \multirow{2}{*}{0.699868} & \multirow{2}{*}{0.347767} \\
\hline & 220 & 99.439 & 0.867769 & 0.449443 & & & \\
\hline \multirow{2}{*}{4} & 101 & 44.821 & 0.391137 & 0.141215 & \multirow{2}{*}{0.350545} & \multirow{2}{*}{0.700578} & \multirow{2}{*}{0.302349} \\
\hline & 220 & 99.268 & 0.866277 & 0.467061 & & & \\
\hline \multirow{2}{*}{5} & 101 & 44.873 & 0.391591 & 0.149145 & \multirow{2}{*}{0.350637} & \multirow{2}{*}{0.700292} & \multirow{2}{*}{0.395134} \\
\hline & 220 & 99.326 & 0.866783 & 0.377454 & & & \\
\hline \multirow{2}{*}{6} & 101 & 44.892 & 0.391757 & 0.142387 & \multirow{2}{*}{0.350609} & \multirow{2}{*}{0.700111} & \multirow{2}{*}{0.374109} \\
\hline & 220 & 99.357 & 0.867053 & 0.380603 & & & \\
\hline
\end{tabular}


The analysis of the physical broadening of the (101) and (220) ferrite lines showed that the maximum hardening corresponds to sample No. $1\left(\beta_{(101)}=\right.$ $\left.=0.277 \mathrm{deg} ; \beta_{(220)}=0.750 \mathrm{deg}\right)$, where the milling mode is traditional at a speed of $45 \mathrm{~m} / \mathrm{min}$.

As a result of the studies, it was found that with an increase in the cutting speed, the hardening degree for the surface layer of 30HGSA steel samples decreases.

In addition, the phase composition was determined using a DRON-4 X-ray diffractometer. The main phases in all the studied samples are ferrite, i.e. a solid solution based on $\alpha$-iron and iron carbide $\mathrm{Fe}_{3} \mathrm{C}$.

The analysis of residual stresses in the surface layer of 30HGSA steel samples was carried out on a $\mathrm{PSF}-3 \mathrm{M}$ "RIGAKU" residual stress analyzer in $\mathrm{Cr}-\mathrm{K}_{\alpha}$ radiation using the iso-slope method, where the voltage was $30 \mathrm{kV}$ and the current was $8 \mathrm{~mA}$. The calculation of the residual stress values was done according to the $\sin ^{2} \psi$ method [20]. The measurements were performed in the cutting direction (the movement direction of the cutting edge and the cutter feed) and in the perpendicular direction.

Stresses in the surface layer can be either tensile or compressive, while their magnitude changes significantly with a change in the cutting speed for high-speed milling modes: from 80 to $300 \mathrm{MPa}$ in the cutting direction, from 70 to $180 \mathrm{MPa}$ in the perpendicular direction (Table 5).

On average, the stresses in the surface layer after traditional milling processing are 2-4 times higher than after high-speed processing.

The chemical composition of the samples under study was determined using a QSG 750/1500 spark
Table 5

The results of determining residual stresses

\begin{tabular}{ccc}
\hline & \multicolumn{2}{c}{$\begin{array}{c}\text { The value of residual stresses } \\
\text { in the surface layer*, MPa } \\
\text { Sample No. }\end{array}$} \\
$\begin{array}{c}\text { Along the cutting } \\
\text { direction }\end{array}$ & $\begin{array}{c}\text { Across the cutting } \\
\text { direction }\end{array}$ \\
\hline 1 & $-410 \pm 15$ & $-280 \pm 5$ \\
2 & $-100 \pm 20$ & $70 \pm 10$ \\
3 & $240 \pm 5$ & $115 \pm 5$ \\
4 & $300 \pm 10$ & $180 \pm 10$ \\
5 & $-80 \pm 20$ & $115 \pm 10$ \\
6 & $200 \pm 10$ & $85 \pm 10$
\end{tabular}

$*(+)$ - tensile stresses; $(-)-$ compressive stresses.

vacuum emission spectrometer by OBLF and an Axcios Advanced X-ray fluorescence wave spectrometer by PANalytical B.V. The analysis results of the chemical composition are presented in Tables 6 and 7, respectively.

The locality of the applied methods for chemical analysis along the depth of the analyzed sample was: for optical emission spectroscopy $-500 \mu \mathrm{m}$, for $\mathrm{x}$-ray fluorescence wave spectroscopy $-40 \mu \mathrm{m}$.

The analysis results showed that the chemical composition of the surface layer in the studied samples has not changed. Thus, the transition from traditional milling to high-speed processing with an increase in the cutting speed to $818 \mathrm{~m} / \mathrm{min}$ did not cause a violation of the chemical composition of 30HGSA steel.

Table 6

The analysis results of the chemical composition using the QSG 750/1500 spectrometer

\begin{tabular}{|c|c|c|c|c|c|c|c|c|}
\hline \multirow{2}{*}{ Sample No. } & \multicolumn{8}{|c|}{ The content of chemical elements, $\%$ (by weight) } \\
\hline & $\mathrm{C}$ & $\mathrm{Cr}$ & $\mathrm{Mn}$ & $\mathrm{Si}$ & $\mathrm{Ni}$ & $\mathrm{Cu}$ & $\mathrm{P}$ & $\mathrm{S}$ \\
\hline 1 & 0.285 & 0.908 & 0.889 & 1.012 & 0.175 & 0.219 & 0.0094 & 0.0020 \\
\hline 2 & 0.283 & 0.914 & 0.897 & 1.024 & 0.175 & 0.219 & 0.0098 & 0.0020 \\
\hline 3 & 0.282 & 0.887 & 0.863 & 0.994 & 0.171 & 0.211 & 0.0086 & 0.0017 \\
\hline 4 & 0.278 & 0.902 & 0.876 & 1.021 & 0.171 & 0.218 & 0.0091 & 0.0020 \\
\hline 5 & 0.282 & 0.893 & 0.866 & 1.008 & 0.173 & 0.216 & 0.0083 & 0.0020 \\
\hline 6 & 0.278 & 0.903 & 0.880 & 1.011 & 0.175 & 0.216 & 0.0090 & 0.0018 \\
\hline GOST 4543-71 & $0.28-0.34$ & $0.8-1.1$ & $0.8-1.1$ & $0.9-1.2$ & $<0.3$ & $<0.3$ & $<0.025$ & $<0.025$ \\
\hline
\end{tabular}


The analysis results of the chemical composition using the Axcios Advanced spectrometer

\begin{tabular}{cccccccc}
\hline \multirow{2}{*}{ Sample No. } & \multicolumn{7}{c}{ The content of chemical elements, \% (by weight) } \\
& $\mathrm{Cr}$ & $\mathrm{Mn}$ & $\mathrm{Si}$ & $\mathrm{Ni}$ & $\mathrm{Cu}$ & $\mathrm{P}$ & $\mathrm{S}$ \\
\hline 1 & 0.89 & 0.89 & 1.06 & 0.17 & 0.212 & 0.013 & 0.012 \\
2 & 0.86 & 0.89 & 1.08 & 0.17 & 0.211 & 0.014 & 0.010 \\
3 & 0.88 & 0.89 & 1.04 & 0.17 & 0.214 & 0.011 & 0.009 \\
4 & 0.90 & 0.89 & 1.00 & 0.17 & 0.216 & 0.013 & 0.009 \\
5 & 0.89 & 0.89 & 1.05 & 0.16 & 0.213 & 0.013 & 0.011 \\
GOST 4543-71 & 0.90 & 0.88 & 1.02 & 0.17 & 0.221 & 0.012 & 0.009 \\
\hline
\end{tabular}

\section{Conclusion}

It was found that high-speed milling of $30 \mathrm{HGSA}$ steel does not lead to deformation changes in the surface layer, while the damage to the surface layer was noted during traditional milling at a speed of $45 \mathrm{~m} / \mathrm{min}$ (Fig. 7). High-speed milling processing of EP817 steel leads to deformation changes in the surface layer at cutting speeds of 273, 636 and $818 \mathrm{~m} / \mathrm{min}$ (Fig. 6). X-ray structural phase analysis of $30 \mathrm{HGSA}$ steel samples showed that the phase composition does not change, and the hardening degree in the surface layer decreases with an increase in the cutting speed. The analysis of residual stresses in the 30HGSA steel samples pointed out that traditional milling processing leads to compressive stresses, while high-speed processing leads to both compressive and tensile stresses on the surface layer. According to the results of determining the chemical composition of the surface layer of 30HGSA samples using the methods of optical emission and X-ray fluorescence wave spectroscopy, no changes in the chemical composition were detected.

For 30HGSA steel, an increase in the milling speed generally leads to an improvement in the state of the surface layer; for EP817 steel, additional studies are required in order to establish the effect of high-speed milling processing on the state of the surface layer.

\section{Acknowledgements}

The authors are grateful for the help and assistance in conducting X-ray diffraction and chemical analysis to the specialists of FSUE "VIAM".

\section{References}

1. Sulima A.M., Shulov V.A., Yagodkin Yu.D. Poverhnostnyj Sloj $i$ Ekspluatatsionnye Svojstva Detalej Mashin [Surface layer and operational properties of machine parts]. Moscow: Mashinostroenie, 1988. (Rus)

2. Papshev D.D. Povyshenie Ekspluatatsionnyh Svojstv Detalej Sposobami Deformasionnogo Poverhnostnogo Uprochneniya. Poverhnostnyj sloj $i$ ekspluatatsionnye svojstva detalej mashin $i$ priborov [The surface layer and performance properties of machine parts and devices]. Moscow: MDNTP, 1984, 74-77. (Rus)

3. Suslov A.G. Kachestvo Poverhnostnogo Sloya Detalej Mashin [The quality of the surface layer of machine parts]. Moscow: Mashinostroenie, 2000. (Rus)

4. Suslov A.G. Tekhnologicheskoe Obespechenie Parametrov Sostoyaniya Poverhnostnogo Sloya Detalej [Technological support for the state parameters of the surface layer of parts]. Moscow: Mashinostroenie, 1987. (Rus)

5. Suslov A.G., Fedorov V.P., Gorlenko O.A. Tekhnologicheskoe Obespechenie $i$ Povyshenie Ekspluatatsionnyh Svojstv Detalej $i$ ih Soedinenij [Technological support and improving the operational properties of parts and their connections]. Moscow: Mashinostroenie, 2006. (Rus)

6. Ivashchenko A.I. Korrelyatsionnyj Analiz Zavisimosti Predela Vynoslivosti ot Urovnya Ostatochnyh Napryazhenij. Povyshenie effektivnosti ispol'zovaniya rezhushchih instrumentov pri obrabotke aviacionnyh materialov: Sbornik nauchnyh trudov [Improving the efficiency of using cutting tools in the processing of aircraft materials: Collection of scientific papers]. Kujbyshev KuAI, 1983, 17-20. (Rus)

7. Podzej A.V., Serebrennikov G.Z. Tekhnologicheskie Ostatochnye Napryazheniya [Technological Residual Stresses]. Moscow: Mashinostroenie, 1973, 213 p. (Rus) 
8. TU 14-1-2407-78. Stal' Sortovaya Korrozionnostojkaya Marki 06H14N6D2MBT-SH (EP817SH) Elektroshlakovogo Pereplava. Tekhnicheskie Usloviya [Corrosion-resistant high-quality steel of grade 06H14N6D2MBT-SH (EP817-SH) of electroslag remelting. Specification]. (Rus)

9. GOST 11268-76. Tekhnicheskie Usloviya. Prokat Tonkolistovoj Special'nogo Naznacheniya iz Konstruktsionnoj Legirovannoj Vysokokachestvennoj Stali [Specification. Special-purpose rolled sheets of structural alloyed stainless steel]. (Rus)

10.Mezhgosudarstvennyj standart GOST 4543-71. Tekhnicheskie Usloviya. Prokat iz Legirovannoj Konstrukcionnoj Stali [Specification. Rolled alloyed structural steel]. (Rus)

11.Metodicheskie ukazaniya i Teoriya Podgotovki Materialograficheskih Obraztsov "Metalog Guide Struers $A / S$ " [Guidelines and theory of preparing materialographic samples «Metalog Guide Struers $\mathrm{A} / \mathrm{S} »], 2011$. (Rus)

12.Bekkert M., Klemm H. Sposoby Metallograficheskogo Travleniya. Spravochnik [Methods of metallographic etching. Reference book]. Moscow: Metallurgiya, 1988. (Rus)

13.Kovalenko V.S. Metallograficheskie Reaktivy. Spravochnik [Metallographic reagents. Reference book]. Moscow: Metallurgiya, 1988. (Rus)

14.Vashul' H. Prakticheskaya Metallografiya. Metody Izgotovleniya Obraztsov [Practical metallography. Sample manufacturing methods]. Moscow: Metallurgiya, 1988. (Rus)

15.Bolhovitinov N.F., Bolhovitinova E.N. Atlas Makro- i Mikrostruktur Metallov $i$ Splavov [Atlas of macro and microstructures of metals and alloys]. (Rus)

16.Bernshtejn M.L., Rahshtadt A.G. Metallovedenie $i$ Termicheskaya Obrabotka Stali [Metallurgy and heat treatment of steel]. Vol. I. Metody Ispytanij i Issledovaniya. Moscow: Metallurgiya, 1983, 352 p. (Rus)
17.Klejner L.M., Kogan L.I., Entin R.I. Svojstva Nizkouglerodistogo Legirovannogo Martensita [Properties of low-carbon doped martensite]. FMM, 1972, 33 (4), 824-830. (Rus)

18.Kuritsyn V.N., Kravchenko I.B. Opredelenie Glubiny Uprochneniya Poverhnostnogo Sloya Detali pri Mekhanicheskoj Obrabotke. Obrabotka vysokoprochnyh stalej $i$ splavov instrumentami iz tverdyh sinteticheskih materialov: Mezhvuz. sb. nauch. tr. [Processing of high-strength steels and alloys with tools made of solid synthetic materials: Interuniversity collection of scientific papers]. Kujbyshev, 1978. (Rus)

19. Gorelik S.S., Skakov Yu.A., Rastorguev L.N. Rentgenograficheskij $i$ elektronno-opticheskij analiz: Ucheb. posobie dlya vuzov [X-ray and electron-optical analysis: Textbook for universities]. Moscow: MISiS, 2002, 360 p. (Rus)

20.Umanskij Ya.S., Skakov Yu.A., Ivanov A.N., Rastorguev L.N. Kristallografiya, Rentgenografiya $i$ Elektronnaya Mikroskopiya [Crystallography, radiography and electron microscopy]. Moscow: Metallurgiya, 1982, 632 p. (Rus)

21.Bernshtejna M.L., Rahshtadta A.G. Metallovedenie i Termicheskaya Obrabotka Stali: Sprav. Izd. [Metallurgy and heat treatment of steel: Ref. Ed.]. Vol. I. Metody ispytanij i issledovaniya. Moscow: Metallurgiya, 1983, 352 p. (Rus)

22.Shmitt-Tomas K.G. Metallovedenie dlya Mashinostroeniya. Spravochnik [Metallurgy for mechanical engineering. Reference book]. Moscow: Metallurgiya, 1995, 512 p. (Rus)

23.Belov A.F., Benediktova G.P., Viskov A.S., Nikolenko V.V., Vishnevskij G.E., L.I. Gerasimova, Karpman M.G., Klypin A.A., Morozova T.S., Potemkin A.Ya., Ryabchenko E.V., Terent'eva V.S., Frolov Yu.P. Stroenie i Svojstva Aviacionnyh Materialov: Uchebnik dlya vuzov [The structure and properties of aviation materials: Textbook for universities]. Moscow: Metallurgiya, 1989, 368 p. (Rus) 